\title{
RDMS CMS computing: current status and plans
}

\author{
V. B. Gavrilov', I. A. Golutvin ${ }^{2}$, O. L. Kodolova ${ }^{3}$, V. V. Korenkov ${ }^{2, a}$, \\ L. G. Levchuk ${ }^{4}$, S. V. Shmatov', E. A. Tikhonenko², V. E. Zhiltsov
}

${ }^{1}$ Institute of Theoretical and Experimental Physics, B. Cheremushkinskaya 25, Moscow, 117218, Russia

${ }^{2}$ Joint institute for nuclear researches, Laboratory of Information Technologies, Joliot-Curie, 6, Moscow reg., Dubna, 141980, Russia

${ }^{3}$ Skobeltsyn Institute of Nuclear Physics, 1(2), Leninskie gory, GSP-1, Moscow 119991, Russia

${ }^{4}$ National Science Center "Kharkov Institute of Physics and Technology”, 1 Akademicheskaya St., Kharkov, 61108, Ukraine

E-mail: ${ }^{a}$ korenkov@jinr.ru

Received October 3, 2014

The Compact Muon Solenoid (CMS) is a high-performance general-purpose detector at the Large Hadron Collider (LHC) at CERN. More than twenty institutes from Russia and Joint Institute for Nuclear Research (JINR) are involved in Russia and Dubna Member States (RDMS) CMS Collaboration. A proper computing grid-infrastructure has been constructed at the RDMS institutes for the participation in the running phase of the CMS experiment. Current status of RDMS CMS computing and plans of its development to the next LHC start in 2015 are presented.

Keywords: grid computing, CMS experiment, RDMS CMS collaboration, CMS Tiers

\section{RDMS CMS компьютинг: текущий статус и планы}

\author{
В.Б. Гаврилов ${ }^{1}$, И. А. Голутвин ${ }^{2}$, О. Л. Кодолова ${ }^{3}$, В. В. Кореньков ${ }^{2}$, Л. Г. Левчук ${ }^{4}$, \\ С. В. Шматов ${ }^{2}$, Е. А. Тихоненко ${ }^{2}$, В. Е. Жильцов ${ }^{2}$ \\ ${ }^{1}$ Институт Теоретической и Экспериментальной Физики, Россия, 117218, г. Москва, ул. Большая Чере- \\ мушкинская, д. 25 \\ 2 Лаборатория информационных технологий, Объединенный институт ядерных исследований Россия, \\ 141980, г. Дубна, ул. Жолио-Кюри, д. 6 \\ ${ }^{3}$ Научно-исследовательский институт ядерной физики имени Д. В. Скобельцыьна, Россия, 119991, \\ 2. Москва, Ленинские горы, ГСП-1, д. 1, стр. 2 \\ 4 Национальный научный иентр «Харьковский физико-технический институт», Украина, 61108, \\ 2. Харьков, ул. Академическая, д. 1
}

Компактный мюонный соленоид (CMS) - высокоточный детектор общего назначения на Большом адронном коллайдере (LHC) в ЦЕРН. Более двадцати институтов из России и стран-участниц ОИЯИ вовлечены в коллаборацию RDMS (Россия и страны-участницы) как составной части коллаборации CMS. Для полноценного участия RDMS CMS в действующей фазе эксперимента, в институтах RDMS была создана необходимая компьютерная грид-инфрастуктура. В статье представлены текущий статус компьютинга коллаборации RDMS CMS и планы его развития в контексте следующего старта LHC в 2015 году. (Tiers)

Ключевые слова: грид компьютинг, эксперимент CMS, коллаборация RDMS CMS, центры CMS Citation: Computer Research and Modeling, 2015, vol. 7, no. 3, pp. 395-398.

(C) 2014 Владимир Борисович Гаврилов, Игорь Анатольевич Голутвин, Ольга Леонидовна Кодолова, Владимир Васильевич Кореньков, Леонид Геннадиевич Левчук, Сергей Владимирович Шматов, Елена Александровна Тихоненко, Виктор Евгеньевич Жильцов 
Russia and Dubna Member States (RDMS) CMS collaboration was founded in the 1994 year [Matveev, Golutvin, 1996]. The RDMS CMS takes an active part in the Compact Muon Solenoid (CMS) Collaboration [CMS Collaboration ..., 1994] at the Large Hadron Collider (LHC) [WhatLHC...] at CERN [CERN Web site]. RDMS CMS Collaboration joins more than twenty institutes from Russia and Joint Institute for Nuclear Research (JINR) member states. RDMS scientists, engineers and technicians were actively participating in design, construction and commissioning of all CMS sub-detectors in forward regions. RDMS CMS physics program has been developed taking into account the essential role of these sub-detectors for the corresponding physical channels. RDMS scientists made large contribution for preparation of study QCD, Electroweak, Exotics, Heavy Ion and other physics at CMS. During LHC Run I RDMS scientists contributed significantly to data taking, data processing and analysis. They played key roles in Higgs hunting, testing the standard model and looking for new physics with CMS. The overview of RDMS CMS physics tasks and RDMS CMS computing activities are presented in [Gavrilov V. et al., 2004; Gavrilov V. et al.. 2006; Gavrilov V. et al., 2008, p. 203-208; Gavrilov V. et al., 2008, p. 156-159; Gavrilov V. et al., 2011]. RDMS CMS computing support should satisfy the LHC data processing and analysis requirements at the running phase of the CMS experiment [CMS Collaboration ..., 2005].

During the last decade, a proper grid-infrastructure for CMS tasks has been created at the RDMS CMS institutes, in particular, at Institute for High Energy Physics (IHEP) in Protvino, Joint Institute for Nuclear Research (JINR) in Dubna, Institute for Theoretical and Experimental Physics (ITEP) in Moscow, Institute for Nuclear Research (INR) of the Russian Academy of Sciences (RAS) in Moscow, Skobetsyn Institute for Nuclear Physics (SINP) in Moscow, Petersburg Nuclear Physics Institute (PNPI) of RAS in Gatchina, P.N.Lebedev Physical Institute (LPI) in Moscow and National Scientific Center Kharkov Institute of Physics and Technology (NSC KIPT) in Kharkov. In the CMS global grid-infrastructure these RDMS CMS sites operate as CMS centers of the Tier-2 level with the following names: T2_RU_IHEP, T2_RU_JINR, T2_RU_ITEP, T2_RU_INR, T2_RU_SINP, T2_RU_PNPI, T2_UA_KIPT, T2_RU_RRC_KI.

A stable and successful operation of several RDMS CMS Tier2 centers and years of operating experience lead to creation the CMS Tier-1 center in Russia as an integral part of the central data handling service of the CMS Experiment (CMS Tier-1 in Dubna). Currently, the JINR realizes a largescale project to create a Tier1 computer center for the CMS experiment in the accordance with a decision (adopted by the WLCG project in 2011) to construct a Tier1 level distributed center for the LHC experiment in Russia on the base of RCC «Kurchatov institute» and JINR. Tier1 center for CMS at JINR is now at a testing phase and a full-scale CMS Tier1 at JINR will be operational in 2015 [Astakhov N. S. et al., 2012].

In line with the CMS computing requirements for the data-taking phase of the experiment, now the RDMS CMS grid-sites provide:

- the computing and data storage resources in full;

- centralized deployment of actual versions of CMS specialized software (CMSSW);

- data transfers between the CMS grid-sites with the usage of the FTS grid-service on basis of VOBOX grid-services for CMS with the Phedex Server;

- SQUID proxy-servers for the CMS conditions DB access;

- certification of network links at the proper data transfer rates between JINR and CMS Tier1 and Tier2 centers;

- daily massive submission of CMS typical jobs by the CMS Hammer Cloud system;

- CMS data replication to the JINR data storage system in the accordance with RDMS CMS physicists' requests;

- participation in the CMS Monte-Carlo physical events mass production in the accordance with the RDMS CMS physicists' scientific program.

As it can be seen from Fig.1, during 2010-2013 years the contribution of RDMS CMS sites intoCMS jobs processing is at level of $5 \%$. 


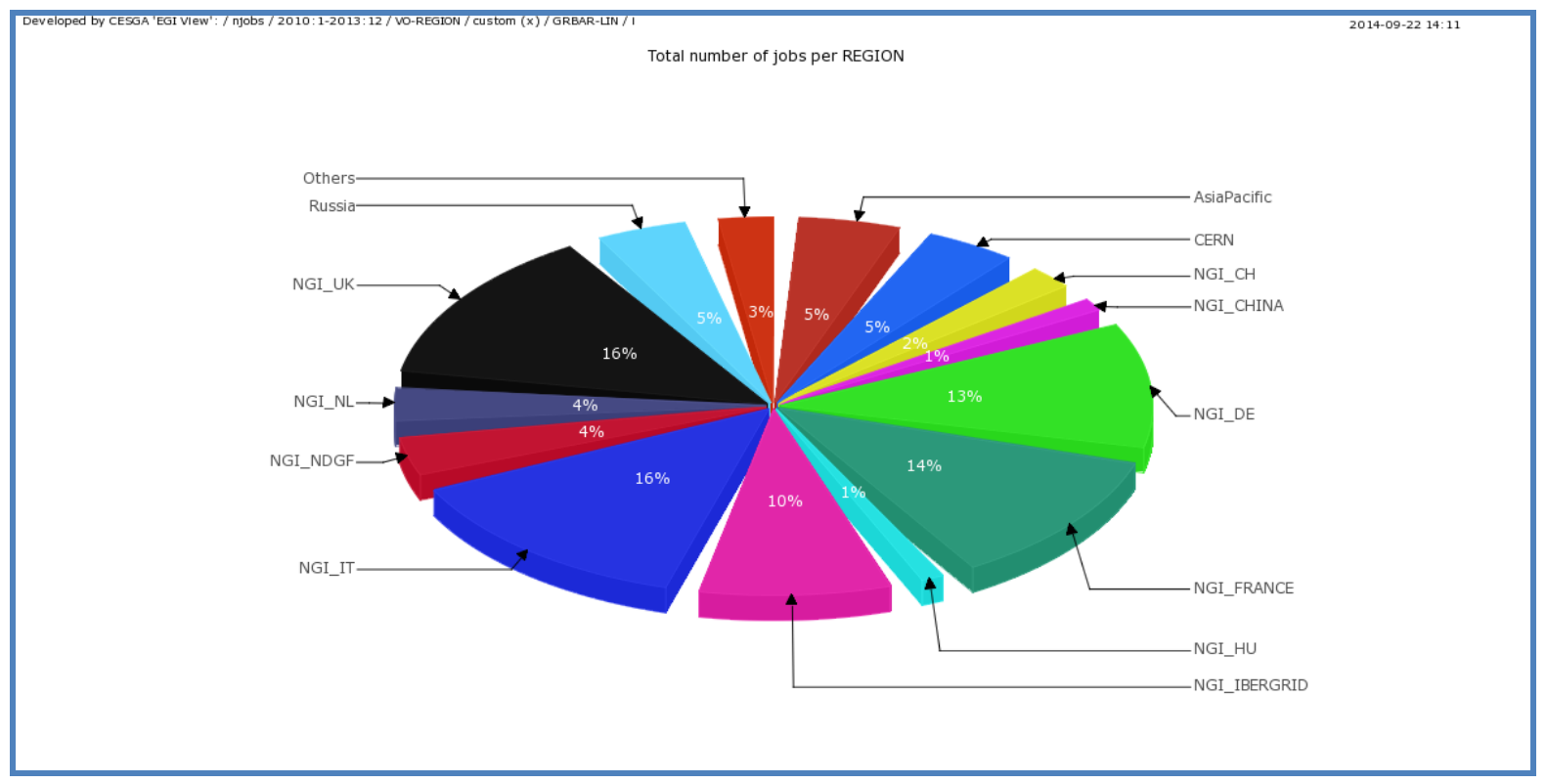

Fig. 1. Number of jobs in CMS Virtual Organization from January, 2010 to December, 2013

From the middle of 2010 to the end of 20132 Petabytes data have been transferred to RDMS CMS sites. By the moment about 1.5 Petabytes of CMS data are stored at RDMS CMS sites (0.5 Petabytes are the data of CMS physical groups with which the RDMS sites are associated).

A group of RDMS CMS specialists takes an active part in the CMS Dashboard development (grid monitoring system for the CMS experiments) (/http://dashboard.cern.ch/cms).

The dedicated CMS remote worldwide-distributed centers (ROC) were built in different scientific organizations. The JINR CMS Remote Operation Center (ROC) was founded in the 2009 year to provide participation in CMS operations of a large number of RDMS CMS collaborating scientists and engineers. MSU and IHEP ROCs were started-up two years after. RDMS CMS ROCs provide the following functions:

- monitoring of CMS detector systems;

- data monitoring and express analysis;

- shift operations;

- communications of the JINR shifters with personal at the CMS Control Room (SX5) and CMS Meyrin centre;

- communications between JINR experts and CMS shifters;

- coordination of data processing and data management;

- training and information .

RDMS CMS physicists work in the WLCG environment, and now we are having more than 30 members of CMS Virtual Organization.

\section{Summary}

The RDMS CMS computing centers have been integrated into the WLCG global gridinfrastructure providing a proper functionality of grid services for CMS. A significant modernization of the RDMS CMS grid-sites has been accomplished. As result, computing performance and reliability have been increased. In the frames of the WLCG global infrastructure the resources of the both computing centers are successfully used in a practical work of the CMS virtual organization. Regular testing of the RDMS CMS computing centers functionality as grid-sites is provided.

All the necessary conditions for CMS data distributed processing and analysis have been provided at the RDMS CMS computing centers (grid-sites). It makes possible for RDMS CMS physicists to take a full-fledged part in the CMS experiment. 
RDMS Tier2 sites contribute significantly to the CMS data processing and analysis tasks. CMS Regional Operation Centers in JINR, MSU and IHEP are operated for remote monitoring of detector systems and data express-analysis.

The nearest plans are to continue support RDMS CMS sites with increasing CPU resources by $14 \%$ and disks resources by $4 \%$ in 2014 and by $25 \%$ and $16 \%$ in 2015 accordingly; in further years - increasing of resources by $10-15 \%$ annually.

\section{References}

Astakhov N. S. et al. Creation at JINR of the data processing automated system of the TIER-1 level of the experiment CMS LHC // Proc. of GRID’2012 conference, Dubna, 2012. P. 254 (in Russian).

CERN. http://www.cern.ch

CMS Collaboration, Technical Proposal, CERN/LHCC, 94-38, 1994 - http://cmsinfo.cern.ch

CMS Collaboration, The Computing Project, Technical Design Report, CERN/LHCC-2005-023, CMS TDR 7, 2005.

Gavrilov V. at al. Current Status of RDMS CMS Computing // Proc. of the XXI Int. Symposium on Nuclear Electronics and Computing, Dubna, 2008. P. 203-208.

Gavrilov V. at al. RDMS CMS Computing activities before the LHC startup // Proc. of 3rd Int. Conference "Distributed Computing and GRID-technologies in Science and Education", Dubna, 2008. P. 156-159.

Gavrilov V. et al. RDMS CMS Computing // Proc. of the 2nd Int. Conference "Distributed Computing and Grid-Technologies in Science and Education", Dubna, 2006. P. 61.

Gavrilov V. et al. RDMS CMS Computing Model // Proc. of the Int. Conference "Distributed Computing and Grid-Technologies in Science and Education", Dubna, 2004. P. 240.

Gavrilov V. et al. RDMS CMS data processing and analysis workflow // Proc. of XXIII Int. Symp. on Nuclear Electronics \& Computing (NEC'2011), Dubna, 2011. P. 148-153.

Matveev V., Golutvin I. "Project: Russia and Dubna Member States CMS Collaboration / Study of Fundamental Properties of the Matter in Super High Energy Proton-Proton and NucleusNucleus Interactions at CERN LHC", 1996-085/CMS Document, 1996 - http://rdmscms.jinr.ru

WhatLHC. http://public.web.cern.ch/Public/Content/Chapters/AboutCERN/CERNFuture/WhatLHC/ WhatLHC-en.html 